\title{
Hitler's Policy Towards Iraq 1933-1945
}

\author{
Muna Mohammed Hassoon
}

Instructor, Professor Ph.D., The Open Educational College, Ministry of Education, Iraq. muna7978@gmail.com

\begin{abstract}
This study demonstrates the Germany's policy towards Iraq after the arrival of the Nazis to power in 1933 till the end of World War II. Because of the geopolitical importance of Iraq, and specifically after its independence and its entry into the League of Nations in 1932, the international parties became in a struggle to dominate Iraq in particular, and the Middle East in general. The study aimed to shed light on Hitler's policy of dominating the Western influence in Iraq, occupying new areas in order to penetrate his power and control, and in his desire to acquire Europe, he was striking the influence of his enemies, especially Britain. The study identified a problem that was based on Germany's betting on time as a significant factor, and how it could be used to serve its strategic plan, taking into account Britain's pressure and its interests in Iraq. The study came out with many conclusions, the most important of which is Germany's growing role to find a foothold in the Middle East, as well as the poor strategic planning of Germany since it did not have any clear goals in that region. In addition, its policy was a reflection of the plans of its allies. The structure of the study was divided into an introduction, and three axes: first, German-Iraqi relations 19191939; second, World War II and the Iraqi stance of it it; third, May's movement 1941 and the German attitude of it, finally, the Conclusion which included the most important findings and recommendations, namely: 1- The growing role of Germany to find a foothold In the Middle East after it achieving its national unity in 1870. However, the German penetration in Iraq was not easy as it was interrupted by many challenges caused by the major countries, particularly Britain. 2- the Germanic strategic planning in the Middle East was poor because it did not have clear goals in the region. Its movements there came as if they were only a reaction to the Allied plans and the depletion of Britain's power. 3- Germany's defeat in the First World War made it interested in restoring its position in Europe and improving its internal conditions, which led to the decline of its international relations with other countries, including Iraq. 4- The developments in Iraq in 1941 provided a valuable opportunity for Germany, but its military failure in its war operations affected its political activities in Iraq to the extent that it ended the German role in Iraq. 5- Germany's failures began in the last years of the war that reached its climax in 1943, signaling the end of Germany's aspirations in the East in general and Iraq in particular. Hence, an important stage of the German activities had ended in which Iraq was an arena for conflict between Britain and Germany.
\end{abstract}

\section{Introduction}

After achieving its political unity in 1871, Germany began to precede it economic and social progress, joining the most advanced European countries. Then, it started to surpass those countries in a record time with the help of different factors, among which are the seizure of Alsace and Lorraine, and the war compensations it obtained from France after its decisive victory over it in September 1870 (Muhammad Muhammad Salih et al, 1985). In less than half a century (1870-1913), rarely in history, Germany enhanced its social, economic, and political unity. It preceded Britain, the first home of the Industrial Revolution, in the field of industrial production and foreign trade, and ranked the second after the United States of America in the international industrial production at the beginning of the twentieth century. All this coincided with the distribution of the best colonies among the major European countries (Hashem Saleh al-Tikriti, 1986; Muhammad Kamal al-Desouki, 1969; Riad al-Samad, 1983). The German foreign policy shifted from the principle of preserving the status quo and alliances to a policy of relying on its own capabilities, going out of Europe's geographical borders, and finding a place for Germany under the sun (Jawad Muhammad Ali Muhammad Ridha, 1982; Ott Hammann, 1926).

The German ruling personnel payed the Middle East a special attention and importance not only for its need for markets and raw materials, but also for its being more acceptable among the peoples and rulers of the East than most other international parties. The Germans chose to export military expertise, as well as good and cheap 
goods as an ideal means of penetration and competition. Thus, in a short period of time, the German presence in the Ottoman Empire turned into an influential reality. German exports to the Ottoman Empire increased in the last decade of the nineteenth century by $350 \%$ (ZY Hershlag, 1973; Muhammad Kamal al-Desouki, 1976).

So, the German policy of expansion began by acquiring colonies. Further, as a result of the complete control of the great powers over all continents, Germany found its way in the Ottoman Empire, whose one of its most important possessions is Iraq (Abd al-Fattah Ibrahim, 1935).

The German approach to Iraq was not spontaneous; rather, it came for several reasons, including its strategic location, its economic potentialities, its cultural treasury, as well as the discovery of oil there since the beginning of the nineteenth century. Thus, Iraq occupied a distinguished position in the aspirations of politicians and German writers, especially between 1871 and 1914. Then, it acquired an advanced position among the leaders of Germany who wished to make it one of the colonies of the German Reich. As Evans Levy stated, one of the German expansionists, controlling Iraq and the Minor Asia was a first step to placing the entire East region under the German control as a prelude to extending the influence of Germany over the world (Jawad Muhammad Ali Muhammad Rida, 1982).

German politics, parties, money-holders, expansionists, and settlement advocates started planning controlling Iraq. The economic side took an important role in the German approach to Iraq due to the increase in the German population as a result of the high standard of living and the increase of income. Therefore, Germany needed foodstuffs and agricultural materials necessary for industry such as cotton. They also need large quantities of raw materials in the cheapest prices and new markets for the disposal of surplus from German industry (Jawad Muhammad Ali Muhammad Ridha, 1982). The Germans also sought to invest and discover mineral resources in Iraq, oil in particular, which has become of great importance at the beginning of the twentieth century due to its use for military and industrial purposes. This came when Iraq's oil was the first major site for production in the Arab world. Thus, Germany became at the beginning of the twentieth century one of the countries that exploited Iraqi oil (George Lonsuchki, 1961; Hikmat Sami Suleiman, 1958). Britain, on the other hand, found in this interference a threat to its political and economic interests in Iraq, the Arab Gulf, and India, after being a strong distinctive country in its colonies spread over the five continents. It was the focus of international conflicts and the global colonial movement until the First World War (Mahmoud Abdel Wahid Mahmoud, 1993). We must bear in mind that Britain had precedence in all issues in the region, which worked to preserve the road leading to India through Iraq and the Arabian Gulf when the Ottoman Empire granted the concession to extend the Baghdad-Berlin railway in 1902 (Qutayba Abdullah Abbas AlBadri, 2011). This prompted Britain to settle its secondary problems with other countries, France and Russia in particular, and as a result there was a conflict between the two countries whose were revealed by the great competition between British and German oil interests in obtaining oil concessions in Iraq (Nuri Abd al-Hamid Khalil, 1975; Muhammad Saleh Mansi, 1972).

This rapid advance of Germany in Iraq aroused Britain's fears and concern, which led it to negotiations with Germany, ended with an agreement signed by the British Foreign Minister, Adore Gray and the German ambassador in Britain, Lihnowsky. This agreement is known as 'Peace of Baghdad' last from 10 December 1905 to10 December 1916. It stipulated that Britain recognized the German-Ottoman interests in the Baghdad-Berlin railway line from Haydar Pasha to Basra. This agreement promised a success for German diplomacy, but World War I prevented its authentication (Jawdat Jalal Kamel Abdul Latif, 2013). Upon the outbreak of the First world War (1914-1918), Britain decided that if the Ottoman Empire participated in the war, it would not be on its side in order to divide its possessions, dealing 
with the fact that the Ottoman Empire had transformed before the war into a purely German region. Moreover, Britain made the Ottoman Empire be on the side of its enemies (The Central Countries) after the incident of the two warships (Queen) and (Breslaw) (Ala Hamzah Al-Fatlawi, 2009). Britain achieved what they wanted by making the Ottoman Empire participating in the war on the side of Germany on October 30, 1914, and Iraq was one of the front regions of the war. After that Britain conmmenced its campaign of occupying Iraq (Ala Hamzah Al-Fatlawi, 2000). Germany, from its part, provided the Ottoman army with technical expertise and military assistance to withstand the advancing British forces to occupy Iraq. It sent many officers to Iraq to provide advice and support to the Ottoman forces. Those officers, with their experience in wars, were able to help the Ottoman army in Stopping the British forces towards Baghdad and sometimes forcing them to retreat. Therefore, Iraq was one of the battlefronts between the two camps. As the British forces advanced north towards Baghdad, the German commander Von Der Gultz managed to defeat the British forces after besieging them in Kut and forcing the British commander Townshend to surrender after a siege that lasted for four-month. Nevertheless, the death of the German commander Goltz, and the withdrawal of part of the Ottoman forces to other fronts outside Iraq facilitated the advance of British forces towards Iraq and its occupation on March 11, 1917 (Russell Brown, 1985; (Abd alRazzaq al-Hasani, 1948).

\section{First: German-Iraqi relations 1919-1939}

The First World War ended, with the victory of the Allied Powers and the defeat of the Central Powers. The Ottoman Empire concluded the Armistice of Mudros on November 1, 1918. This ensured Britain's control over the area between the Mediterranean and the Arab Gulf. Germany was no longer one of the influential powers in the Near and Middle East. According to the Treaty of Versailles (1919), the Germans were forced to give up their overseas possessions, their rights and all their special privileges in the countries of
European states. Germany had also lost all its privileges and possessions in the Ottoman Empire and in Bulgaria. After the defeat, Germany was only left with a small portion of its broad economic activity and political influence in the Near and Middle East (Sami Muslim, 1985; Morris Croese, 1970). In spite of this, the policy of expansion towards the East remained the prominent feature that distinguishes German foreign policy. This expansionist policy towards the East was under glamorous slogans, and deceitfulness such as understanding with people for peace and democracy. During the era of the Weimar Republic that was established in 1919, the style of the German colonial policy changed, especially after the collapse of the Ottoman Empire, when the Germans started calling out the slogan ... "The Arab, and the Germans are the ones who were deceived by Versailles Agreement and are the first victims of colonialism ..." (Mona Muhammad Hassoun Al-Saadi, 2017). Germany adopted a new policy and showed those peoples that it is the righteous anti-colonial country in support of the struggle of the people of this region against foreign domination. All this was to facilitate the task of peaceful incursion into these countries to achieve a policy of colonial expansion (Adnan Rashid, 1978).

The Weimar Republic faced extremely complex problems. The most prominent of which was the problem of compensation contained in the Treaty of Versailles as it had to pay 300 million gold marks annually to pay back the compensation amounted to 132 billion marks from the Treaty of Versailles. Thus, because of treaty, the war compensations imposed on Germany was an extra burden added to its collapsing economy. The German individual now lives below the level of subsistence and in conditions of severe hunger (Nassif Jasim Abbas Al-Ahbabi, 1994; Nassif Jasim Abbas Al-Ahbabi, 1989).

The new situation in Germany has led to a radical change in its foreign policy; the ultimate purpose of the German foreign policy has become to reconsider the Treaty of Versailles, to liberate from the heavy restrictions it imposed, as well as 
to restore Germany's position in Europe. As a result of this was the freezing of Germany's activity. Its financial investments have weakened in the Arab countries that were part of the Ottoman Empire (Lucaz Herzways, 1968; Ali Muhafaza, 1985). Hence, the Germanic political and economic activities declined in the Middle East in general, and Iraq in particular, (Sami Muslim, 1985).

As for the political relations between the two countries, they witnessed a tangible development. In 1921, the German government sought to establish new consulates in the countries affiliated with the British crown. A year and a half after the signing of the Treaty of Versailles Germany was able establish its own consular representation. The British government made clear its initial agreement to re-establish German consulates in the United Kingdom, as well as in the colonies, and this was achieved by Germany's recognition of the Treaty of Versailles. This helped the Germans to overcome the British objections against the German consulate whose main concern is to protect the German commercial interests, and not to fulfill political duties (Mahmoud Kassim, 2000). The first German attempt to restore relations with Iraq was via a request presented by Germany through its embassy in London, seeking to appoint a consul for it in Baghdad. The approval was obtained on December 7, 1926 to appoint William Litan as consul in Baghdad. The opening of the German consulate was on January 7, 1927, and the archaeologist, Juleus Jordan, was appointed a consulate on January 9, 1930 (Fritz Groppa, vol.1, 1979).

This development had a major role in revitalizing trade and economic relations between the two countries. Progress was noticed in the export of German goods to Iraq, but this was not associated with a similar increase in Iraqi exports to Germany (Hussein Tohme Shathir, 1988). In 1928, a team of scientists consisting of eleven scientists arrived to Kirkuk exploring for oil after an agreement was concluded for this purpose between the German company, Simians, and the
Turkish Oil Company (Jawdat Jalal Kamel Abdul Latif, 2013). In the meantime, King Faisal I visited Berlin on August 8, 1930 as part of a European tour, with the aim of not provoking Britain in a critical period that accompanied the signing of the 1930 Treaty. Faysal met the German President Hindenburg (Hindenburg 19251934) and a number of German officials. He also met a number of money and industry men for whom he indicated his desire for the contribution of German companies in the development of Iraq's oil, the use of German expertise, the technical progress for the development of Iraq. He also he urged the German government through it to participate in the concession granted to it by the British Petroleum Development Company. The German officials welcomed this contribution and responded positively to King Faisal's proposals, the work to restore the German activity, and their support for Iraq in the matter of its acceptance in the League of Nations (Jawdat Jalal Kamel Abd al-Latif, 2013; Fritz Groppa, vol.1, 1979). As for the German cultural activity, it was not clear at that time, and it can be summarized by the German government's approval in 1931 to accept two students envoyed from the Iraqi government to the University of Berlin. In July of the same year, the Iraqi government agreed to bring in the German ophthalmologist, Dr. Frances Gouldnar to work in ophthalmology in Mosul (Hussein Tohme Shathir, 1988).

The political situation in Europe made Germany avoid any kind of conflict with the Western powers. This did not apply only to Europe, but also to the eastern countries. In 1926, Germany became a member of the League of Nations, and it could-officially- to have a voice in the matters related to Iraq and Palestine, as they are countries under the British Mandate. But Germany did not benefit from these relatively limited resources, as all that was concerned with restoring Germany's position in Europe was; therefore, it was natural that it avoided carrying out any political activity in countries under the British control. (Mona Muhammad Hassoun AlSaadi, 2017). 
After Iraq had fulfilled the conditions that would qualify it to enter the League of Nations, the Council of the League announced that Iraq had been accepted as a member on October 3, 1932. The mandate rule ended, and Iraq became an independent state; this independence; however, did not end the British influence. It was more formal than practical, and realistic. By virtue of the treaty ratified on June 30, 1930, which restricted Iraq's foreign relations, and made it linked to Britain, including the loss of the external aspects of independence, and its many dependencies that were not beneficial to Iraq, while it brought Britain new gains and made the independence of Iraq incomplete (Medal (Hadi Akkar Al-Tamimi, 2010; Farouk Saleh Al-Omar, 1977; Hussein Muhammad al-Shabibi, 1973).

The beginning of the period of Iraqi independence witnessed tangible development in political relations with Germany, especially after Germany supported Iraq's request to enter the League of Nations. It (Germany) announced that it would welcome its admission to membership through the congratulatory telegram sent by the President of Hendenburg to King Faisal I (Abdel Majid Kamel Al-Tikriti, 1991 ), On November 8, 1932. This was well reflected in the relationship between the two countries in variant perspectives. Germany developed its diplomatic representation from a consulate to a commission on October 25, 1932, and Fritz Groppa became plenipotentiary minister and an extraordinary delegate to Germany in Iraq. This procedure met with approval and agreement by the Iraqi government and public opinion. It also promised a gesture to strengthen and consolidate the relations between the two countries ( Hussein Tohme Shathir, 1988).

The rise of Nazism to power with Hitler (Benjamin Eil, 1965; Ali Maulah, C7, 2010; Fritz, Redlich, 1999, on January 30, 1933) was a major turning point, both internally and externally. Hitler tried to impose his influence on the political scene in Germany by liquidating all parties operating in Germany, revoked the powers of local governments, and order the confiscation of the property of the cooperative societies (Mona
Muhammad Hassoun al-Saadi, 2017; Muhammad Shukri Fouad, 1947).

The Nazis took advantage of all the loopholes of the Weimar Republic, and the problems resulting from the global economic crisis (1929-1933) (Faith Mutab Yahya Al-Naimi, 2003) that shook Germany more than any other European country as Hitler promised employing the unemployed Nazis, raise wages, and improve Economic conditions (Mona Muhammad Hassoun Al-Saadi, 2017; The Arab World (newspaper), 1932). By introducing political and economic changes to restore Germany's international standing, by creating foreign markets to obtain the foreign currency from which Germany suffers from shortage. This trend appeared in Hitler's speech on February 3, 1933 in which he expressed his ambition to open the eastern markets to German products and goods, and he considered it a vital area for German products. Since foreign trade was of great importance in the German economy, which was accustomed to producing more than one need in order to be able to import what it needed from the raw agricultural materials (Abbasid Nizam 1945; Hussein Tohme Shathir, 1988).

Although German policy at the beginning of the thirties did not place its priorities in establishing future pillars in the Arab region, including Iraq, due to the lack of the Nazis at the beginning of their access to sufficient strength that enables them to confront the British and French colonialists in the Middle East (Jawdat Jalal Kamel Abd al-Latif, 2013) . Therefore, Germany's commercial dealings with the countries of the Arab East, and Iraq in particular, were small. During this period, the economic relations between Germany and Iraq did not reach the level of ambition. In Iraq, Britain continued to impose its control on foreign trade despite Iraq gaining its independence in 1932. Moreover, Iraqi economy was suffering from in various aspects among which is the decrease in the rates of agricultural production, and the impact of the global economic crisis on it in general (Hussein Tohme Schath, 1988). 
Hence, we can understand the nature of German activity, and its focus on a foreign policy that aimed at expanding its economic activity with Iraq without getting involved in political issues. The German diplomatic activity was represented by Fritz Groppa 1932-1939 and some other German figures who contributed to promoting German culture among the intellectual Iraqis in order to draw attention to Germany. They also aimed at bringing the Iraqi politicians closer together to form economic and political relations with Germany. For this reason, the Iraqi government decided on March 30, 1933 to establish a commission in Berlin, and to appoint a commissioner and a minister for it, based in Rome. The German government welcomed the establishment of the Iraqi commission and in return, the German government intended to expand its diplomatic activity in Iraq by opening a general consulate in Baghdad on April 3, 1933 to be integrated with the Commission and chose for this position the Plenipotentiary Minister Fritz Groppa himself. It even approved his appointment to protect and expand the German commercial interests and entrusted him with signing treaties with Iraq (Hussein Tohme Shathir, 1988).

The British interference in the internal affairs of Iraq, the independence of Iraq, and its entry into the League of Nations are among the most important reasons that prompted some Iraqi politicians to try to get out of the British sphere of influence and, at the same time, to seek to establish balanced relations with other foreign countries to solve some of Iraq's political and economic problems in line with the German trends, which had a lot of supporters in Iraq. This support was after the Germans practiced in Iraq in the thirties a propaganda activity that aimed at countering the growing British influence (Jawdat Jalal Kamel Abd al-Latif, 2013). The promotion of the German role among the Iraqi national elements that expressed their admiration for Germany calling for rapprochement with it in the hope of gaining support for national issues and nationalism for what was known about Hitler's anti-Jewish position, which came in line with the
Arab position calling for the rescue of Palestine from them (D.K.W., 311/762 Royal Court, Iraqi Royal Commission in Berlin, No. S / 318/318/13/1072 dated December 13, 1944 and 38; Ruaa Maher Badri Jabal Al-Janabi, 2014; Ahmad Khudair Abbas, 2014). Meanwhile, after the death of King Faisal I on 8 September 1933, his son Ghazi (1933-1939) assumed the throne (Hussam Al-Samuk, 2005) Ghazi's foreign policy towards some European countries in accordance with the national and international interests of Iraq, and his rapprochement with Germany came as a clear embodiment of this new approach that distanced itself from the British policy which is inconsistent with the Iraqi interests. In addition to his attempt to independence in exercising his constitutional powers to achieve his national and international goals (Majid Khadduri, 1938). Despite Ghazi's admiration of Germany and his attempt to approach it after its rapid progress in the field of armaments in a desire to develop the Iraqi army and supply it with weapons, he was displaying a kind of balance in foreign policy by pursuing a policy that does not contradict the British interests, and his commitment to the provisions of the 1930 Treaty. (Lotfi Jaafar Faraj, 1987). In light of this rapprochement, formal contacts took place between Iraq and Germany, represented by King Ghazi and the German leader Hitler. Hitler congratulated King Ghazi on September 8, 1933 on his assumption of the throne, and King Ghazi made the same initiative on August 22, 1934 on the occasion of Hitler's assumption of the chancellery in Germany (Hussein Tohme Schathir, 1988).

The expansion of Germany's power in the fourth decade of the twentieth century and its need for foreign markets and raw materials led to a rush towards the Arab East. After he was in charged of ruling in Germany, Hitler showed great interest in developing the German economy. Shortly, the German economy began to compete with the British and the French interests in the world, achieving a lot of success in this field $(\mathrm{D}, \mathrm{K}, \mathrm{O}$, 762/311 Royal Court, Iraqi Royal Commission in Berlin, No. S/8/9 dated December 22, 1936, and 
63; Ammar Shaker Mahmoud, 2013). The German exports increased within one year of the Nazis' rule from $(68,462)$ million Marks to $(82,228)$ million (William Sharrer, G1, 1966; Hussein Tohme Shathir, 1988). Germany needed markets to dispose of its products as it has a surplus greater than the relatively cheap industrial production. That was due to the quality of the German goods sold in a relatively low price, and through the profitable commercial deals it concluded with dozens of countries through negotiations that won the admiration of many economists (Nassif Jasim Abbas Al-Ahbabi, 1989; Dr. Shacht, 1937).

The German commercial and economic activity developed in Iraq during this period. On March 31, 1934, the German government provided Iraq with a financial guarantee of (125) thousand pounds to complete oil exploration projects. On June 25 of the same year Germany provided another guarantee of $(500,000)$ thousand pounds to implement a plan of extending a railway from Baiji through Mosul to Tal Kochak on the Iraqi-Syrian border (Fritz Groba, C1, 1979). In addition to other loans that confirmed the development of relations between Iraq and Germany (Fritz Groppa, c.1979). On November 25, 1934, Hitler sent King Ghazi a letter delivered by the Plenipotentiary Minister in Baghdad expressing his desire to consolidate ties of friendship between the two countries. Further, on the occasion of the birth of Prince Faisal II (Tariq Ibrahim Sharif, 2011; Sami Muslim, 1985), Hitler sent a congratulation telegram to King Ghazi, who in turn responded with a thanks telegram (Lotfi Jafar Farag, 1987).

However, during the period (1933-1939), the German-Iraqi relations did not deviate from the commercial and cultural scope. It was natural for the politics of the Third Reich to move in the same direction for some time after the fall of the Weimar Republic in 1933 or later, on the condition that they avoid undertaking any political activity in the countries that are under British and French influence. This is what was confirmed by the East Department of the German Foreign
Ministry on July 17, 1933, which warned against any form of contacts for political cooperation with the Arabs. This department indicated that any step towards them would reach "London and Paris ... as soon as possible." The memorandum also confirmed that Germany's foreign policy will continue in the East as it was in the past since it seeks to take care of its economic interests and refrain from taking any step that might threaten the Britain and France's position in the region (Mona Muhammad Hassoun Al-Saadi, 2017). This policy demanded the availability of a solid economic base whose importance lies in its strong economic structure that strengthens its economic, political and military capabilities. All this, according to the words of William Sher, was with the help of its legacy from the Weimar era and the transformation of the German worker into an industrial slave who is linked to his employer (William Scherer, 1966; Abd Rahman AbdulGhani, 1995). In the commercial field, Germany concluded a trade treaty with Iraq on August 4, 1934. This treaty regulated the commercial movement between the two countries, which witnessed a clear increase during this period. The treaty included seven articles, the basis of which is the treatment of each of the two contracting countries with the other in preferential treatment in matters of customs, freedom of transport, and treatment. This treaty resulted in an increase in Iraqi exports by (26\%) in 1936 from the previous year, and Germany also achieved great benefit as it moved from the tenth place among the countries that import goods from Iraq to the seventh position being ahead of Italy, the Netherlands, and France (Abbasid Nizam, 1984; Abdul-Razzaq AlHasani, Part 4, 1977). In confirmation of working with the contents of the treaty and to support the continuation of commercial cooperation between the two parties, Germany invited Iraqi merchants, days after signing the treaty, to participate in exhibiting their products during its Leipzig International Trade Fair in Germany (Walid Abboud Muhammad Shabib Al-Dulaimi, 1999). In terms of culture, and for the purpose of developing education in Iraq, the Ministry of 
Education brought in the German expert Sohdhoof to consult him in establishing an industrial school in Iraq after the approval of the Iraqi government on January 24, 1934. Sudhoff arrived in Baghdad in April of the same year. After observing the conditions of education, he presented a report to the Iraqi government on the ways of improving the conditions of industrial education in Iraq (Jawdat Jalal Kamel Abdul Latif, 2013).

In the same context, the Iraqi government agreed in 1935 to use the German expert Hoper to deliver lectures in the German language in the Iraqi high schools and to benefit from his wife to teach physical education in the central high school for girls in Baghdad. As for the scientific delegations, and due to Germany's superiority in some important specialties such as medicine and engineering, the Iraqi government sent a number of scientific missions to Germany whose total reached thirty students in 1939 alongside thirty Iraqi students who already were studying in German universities at their own expense. Most of them were affiliated with the College of Medicine (Hussein Tohme Shatter, 1988).

The Iraqi press had a great role in expanding the cultural and scientific relations with Germany via the articles published for this purpose in which it clarifies the scientific position of Germany and the facilities and services it provides to students studying in German universities. This increased the number of applications submitted to the Ministry of Education for the purpose obtaining admissions in Germany (Yunus Bahri, 1968).

In the field of archaeology and excavation, several German archaeological delegations visited Iraq. They worked in many archaeological sites around Iraq and presented studies and carried on research in this field. The Iraqi government contracted with archaeologist and engineers in city engineering to develop a design for the building of the Iraqi Museum as well as a design for a city Baghdad (Hussein Tohme Shathir, 1988).

Thus, Germany has made an evident progress in Iraq, which contributed to the increase of German influence and interests in Iraq. For the purpose of increasing trade cooperation between the two countries, the German Minister of Economy, Dr. Schacht, visited Iraq on November 25, 1936 and met the Iraqi Foreign Minister Naji Al-Aseel and the Minister Finance Jaafar Abu AlTaman. Then Wilham Von Flogai visited Iraq in March 1937, a German specialist whose goal was to find the best ways of commercial cooperation between the two countries since the Iraqi government asked Germany to supply Iraq with some commercial materials through German companies such as power stations. The value of what the Germans exported to Iraq in 1937 ranged from six to seven million marks, and the value of German imports from Iraq of agricultural materials and other materials in the same year amounted to 1.9 million marks. The German institutions showed an increasing interest in Iraq because it was market for the disposal of its industrial materials as well as due to its desire to obtain foreign currency (Hussein Tohma Shazhar, 1988).

As for the military field and defence affairs, to expand the Iraqi army and equipping it by relying on the country's own resources, and to in order reconcile between the military and civilian purposes, Iraq resorted to Germany when the British government hesitated in supplying it with weapons under the pretext that the British army is in need of those weapons, and modern equipment. Accordingly, representatives of German companies such as Rheinmetal Borsing from Berlin and Ottowalf from Cologne presented to Iraq representatives of German companies such as Rheinmetal Borsing from Cologne. The Iraqi Ministry of Defence provided them with lists of their weapons needs to equip the Iraqi army. It was agreed with the two companies to supply Iraq with eighteen $(2 \mathrm{~mm})$ cannons with eighteen thousand shells, the prices of which amounted to about one million marks (Fritz Groppa, G1, 1979).

In response to the German invitation, the Ministry of Education decided to send twenty students from high schools covered by the fatwa system to Germany to participate in the Hitler Youth Assembly, which is held on the occasion of 
the German National Day during the first half of September 1938 (Walid Abboud Muhammad Shabib Al-Dulaimi, 1999). Upon arrival in Germany, the Iraqi delegation received a great welcome, who visited some German historical sites, the Museum of Weapons. Thus, Iraq represented the largest conference that Europe has known in its contemporary history. Upon the delegation's return, the Iraqi Ministry of Foreign Affairs thanked the German government in appreciation for the hospitality with which the delegation was received during its stay in Germany. Germany, and Hitler's reception of the delegation was echoed on the Iraqi radio, which broadcast lengthy details of the Iraqi-German relations and their development (Younes Bahri, 1968; Lotfi Jaafar Farag, 1987).

In order to activate trade exchange between the two countries, the German industrial and commercial companies intensified their activities to conduct numerous deliberations between them and the Iraqi commercial establishments in Baghdad and Basra. They expressed their desire to buy what they need of raw materials such as cotton, leather, grains, and tannins in exchange for what Iraqi merchants imported it from German products of iron, cotton, and woollen textiles. This initiative had a great impact in developing economic relations between Iraq and Germany (Hussein Tohme Shathir, 1988).

The expansion of cooperation between the two countries raised British concerns, especially after it was noticed that the German Minister Plenipotentiary Fritz Groppa was in constant contact with King Ghazi through some nationalist elements that trust the cooperation with Germany. In addition, the British were concern about King Ghazi Radio as it was a manifestation of propaganda for German, and its prejudice against British politics and the threat to their interests. It is known that this radio was Hitler's gift to King Ghazi in 1938. Moreover, the feelings of friendliness shown by the Iraqi public opinion raised Britain's fears and concerns (Yunus Bahri, 1968; Lotfi Jafar Faraj, 1987).
These events coincided with the tense international situation threatening the outbreak of war between the European countries. Therefore, Britain tried to remind the Iraqi politicians of their obligations to the 1930 Treaty, while the German delegation sought to exploit the supportive public opinion to obtain a pledge that Iraq would be neutral, at least in the event of war, and Fritz Groba showed remarkable activity in this regard. He met the Iraqi Prime Minister Jamil al-Madfai (August 17, 1937 - December 25, 1938) (Abd alRazzaq al-Hasani, c.10.1977) and inquired about Iraq's stance on Germany in the event of a war between it and Britain. The Iraqi prime minister replied: "Iraq as an ally, it will be obliged to stop the diplomatic relations with Germany, but he is not obliged to declare war on it." (Fritz Groppa, c.2,1979). But the stance of Iraqi public opinion influenced by Germany and the increase in German propaganda on the side of the Palestinian issue prompted Jamil Al Madfi to change his position. That was during his meeting with Fritz Groppa on September 28, 1938 when he indicated that Iraq, because of its sympathy with Germany, would abide by the side of neutrality in the event of a war between Britain and Germany. He also indicated that he would take advantage of any possible opportunity provided to him by the treaty of 1930 with Britain to postpone the implementation of any decision taken against Germany (Lotfi Jaafar Farag, 1987). After this interview, Groppa realized that Iraqi politics was still restricted by the British policy. What added to this matter was the international situation that warns of the possibility of a war between Germany and Britain. Consequently, it is possible to refer to a state of weakness that had appeared evident in Germany's political relations with Iraq since late 1938 and early 1939 (Yundarevsky, 1977).

Nuri Saeed's assuming the presidency of the government on December 25, 1938 was a further cause for the weakness in the GermanyIraqi relations (Abdul Razzaq Al-Hasani, c. 10, 1977). He was known for his affection for Britain and his opposition to Germany. The shipment of 
German weapons was stopped according to the agreement concluded in late 1938, and the project of establishing the Technical Industrial School stopped In Baghdad, as the German Association for Education had expressed its willingness in December 1938 to build it, Nuri Said emphasized that the idea of establishing the school, which came with the act and encouragement of a group, was intended to be "the nucleus of a subversive institution on behalf of the Germans" (Najda Fathi Safwat, 1984) . In general, the coming of Nuri Said represented an opportunity for Britain, which it tried to exploit in a manner consistent with its interests, at a time when the threat of war was looming on the horizon. (Abdul Razzaq AlHasani, c. 10, 1977). He was known for his affection for Britain and his opposition to Germany. The shipment of German weapons was stopped according to the agreement concluded in late 1938. The project of establishing the Technical Industrial School in Baghdad was stopped as well as the German Association for Education had expressed its willingness in to build it December 1938. Nuri Said emphasized that the idea of establishing the school, which came with the act and encouragement of a group, was intended to be "the nucleus of a subversive institution on behalf of the Germans" (Najda Fathi Safwat, 1984) . In general, the coming of Nuri Said represented an opportunity for Britain, who tried to exploit it in a manner consistent with its interests at a time when the threat of war was looming on the horizon.

\section{Second: World War II and the Iraqi stance}

Events in Europe began moving towards an armed clash after the failure of negotiations between these countries to settle their differences due to Germany's intransigence and its insistence on expansion at the expense of its neighbouring countries. This raised concerns of Britain and France over their influence in the areas that Hitler intends to annex to Germany. About these developments both Germany and Britain began to work through their ambassadors to gain the friendship of the countries in which they worked if war broke out (Shirer, William, 1960). Although the theatre of military operations at the beginning of World War II was far from the Middle East region, the area was the focus of attention of both the warring parties (Najdah Fathi Safwa, 1999; Safir Muhammad al-Saad, 1990).

Naturally, the global crisis caused by the Nazi threat was an occasion to put into effect the provisions of the 1930 Treaty under the political, economic and military privileges contained in the treaty. The British embassy in Iraq used to interpret these texts as requiring Iraq to stand by Britain in the event of war (Mona Muhammad Hassoun al-Saadi, 2017). Thus, her ambassador, Basel Newton visited the Iraqi Foreign Minister Ali Jawdat al-Ayyoubi, asking him to cut ties with Germany and declare war on it. From his turn, Ali Jawdat al-Ayyoubi presented the matter to the Council of Ministers and the latter agreed to cut diplomatic relations with Germany and to deport its citizens outside Iraq. The declaration stated, "Given the current world situation and the confusion that may be generated by the presence of German citizens in Iraq, the council of ministers decided to deport the aforementioned nationals, cease the Iraq's relations with the German government, and authorized the Foreign and Interior Ministers to take the necessary measures for this purpose "(Abdul Razzaq AlHasani, 1971).

These developments were the subject of criticism from some Iraqi politicians. The Minister of Defence Taha Al-Hashemi, the Minister of Justice Mahmoud Subhi Al-Daftary, the Minister of Finance Rustum Haidar, and the Chief of the Royal Court Rashid Ali Al-Kilani, objected to Nuri Al-Saeed's desire to declare war on Germany. The political powers in Iraq considered Nuri's Al-Saeed insistence and his implementation of cutting the relations with Germany a big mistake (Fritz Groppa, part2, 1979). On the same day, the Foreign Minister Ali Jawdat informed the German ambassador Fritz Groppa about the decision of the official Iraqi government and informed him that the German mission must leave Iraq within twenty-four hours through Syria and under police escort. He telegraphed to the Chargé 
d'Affairs of the Iraqi Embassy in Berlin, Atta Amin, to ask the German government to give him his passport and to leave Germany with the staff of the Iraqi commission there (Fritz Groppa, part2, 1979; Abd al-Razzaq al-Hasani, 1971). The regent Abd al-Ilah, On the other hand, sent a telegram to King George VI (1952-1936) confirming Iraq's commitment to the treaty of friendship and alliance with Britain. As for Nuri al-Saeed, he suspended the counsel of Representatives and resorted to issuing decrees that contradict the constitution and aimed at suppressing all opposition to his pro-British policy. Among those decrees were Publication Control Decree No. 54 of 1939, and Emergency Decree No. 57 of the same year, violating the rights and freedoms guaranteed by the constitution to the citizens (Hamed Al-Hamdani, 2016). In implementation of the 1930 treaty, Nuri al-Saeed opened the door wide for British forces to occupy Iraq again, and for Iraq to become a party to a colonial war in which he has no role in it.

Moreover, Nuri Al-Saeed, the Minister of the Interior, issued an order to arrest the German nationals in Iraq and handed them over to the British authorities, who sent them to India as prisoners of war. As for the members of the diplomatic commission, their passports were returned to them in preparation for their travel to Germany. The Afghan embassy took over the German interests in Iraq (Abdul Razzaq AlHasani, Part 5, 1977). In reaction to the news of Iraq's decision to cut the diplomatic relations, the German government besieged the Iraqi Commission House in Berlin and placed it under a police guard. It also cut off the Commission's phone to isolate it from the outside. The Iraqi Charge of the affairs, Atta Amin, protested at the German Foreign Ministry, which confirmed that these procedures came due to the German government's ignorance of the fate of Fritz Groppa and the German nationals in Iraq since the diplomatic ties were cut off. Then, these procedures were eased, the Iraqi mission and nationals began to leave Germany, the Afghan commission was tasked to take care of the Iraqi interests in Germany. With this procedure, Germany had broken its promises that it had expressed to the Iraqi charge of affaires in Berlin before the war. It promised that when the war breaks out, the German government would keep the Iraqi commission in Berlin to carry out its work as usual and the Iraqis would remain in Germany and enjoy their full freedom (Lucas Herzoys, 1968). The decision of the Iraqi government to sever relations was met with interest and satisfaction on the part of the British government. Newspapers also showed interest in the aforementioned decision and praised it (Hussein Tohme Shathir, 1988).

A major change has occurred in the military situation in Europe as a result of the German armies' invasion of Poland, Norway, Belgium, the Netherlands, and Denmark, and their incursion into the French territory. The British and French forces could not withstand them. These developments led to the belief that Britain would fall after France fell. This had an impact on the Iraqi opinion shifting from Britain at a time when Arab efforts failed to obtain its pledge to solve Arab issues, especially with regard to Palestine (D.K.O, Royal Court 729/311, Iraqi Royal Commission in Egypt, book No. 207/5 /th, dated July 1, 1940, and 38; Jaafar Abbas Hamidi, 1976; Moaz Hilal Jasim, 2013; Fouad Sarrouf, 1945; Zigfried Coogelfrantes, 1992). In the meantime, events accelerated, and the military scene developed in the European area. Italy entered the war on the tenth of June 1940 on the side of Germany (K.D.O, the Royal Court 724/311, the Iraqi Royal Commission in Egypt, book number D / 472/472 / 600/1602, December 25, 1943, W 24; Abd al-Khaliq Lashin, 1977; Little Tom, 1967).

The Iraq's decision to wait breaking off its diplomatic relations with Italy came because of the futility of boycotting Germany, which was nothing but courtesy to Britain and an unjustified hostility to Germany. This led to Britain's lack of confidence in the ministry of Rashid Ali al-Kilani (.......) (Abdul Razzaq al-Hasani, (C10, 1977). This decision angered the British ambassador, who hastened to meet the Prime Minister on June 
12, and expressed Britain's concern about the decision, and the government's reluctance to cut ties with Italy. He also informed him that this affects Iraq's credibility in implementing the provisions of the signed coalition treaty in 1930. Britain tried to pressure the Iraqi government with its military methods, so the British embassy notified the Iraqi Foreign Ministry of its decision on June 21, 1940 to land its military forces in Basra for the purpose of heading to Haifa. It requested the permission to establish resting camps in Basra, Baghdad, and Mosul for its air forces. The Iraqi government agreed to this British request (Hamed Al-Hamdani, 2016).

Rashid Ali Al-Kilani undertook direct negotiations with the German side due to British pressure on the one hand and his failure to obtain a promise from Britain regarding Syria and Palestine. The choice to carry out this task was Othman Kamal Haddad, who arrived in Berlin via Ankara on August 26 of the same year (Franz Von Papen, c. 2, 1952), and met Groppa on the same day. Osman Haddad, after securing contact with the Germans, sought for the Axis to recognize the Arab demands, which in turn mean Iraq's willingness to establish diplomatic relations with Germany, declaring its neutrality in war, and removing Nuri al-Saeed from the Foreign Ministry. Further, He requested that the Axis countries have a privileged economic position, investing oil in it, as well as launching revolutions in Palestine and eastern Jordan against Britain in exchange for giving Syria its independence (Ibtisam Hammoud Muhammad, 2009; Fritz Groppa, Part 2, 1979; Massad Rustum Hammadi Al-Rajhi, 2013).

On the other hand, Naji Shawkat left Baghdad on August 2, 1940 to contact the German ambassador in Ankara, von Baben, to complete his discussions with him, carrying with him a draft of the conditions that should be included in the statement to be issued by the Axis countries (Othman Kamal Haddad, 1952). On the 23rd of October 1940, the statement was broadcast by the Berlin and Bari radio stations, but its formulation did not reach the level that would achieve the aspirations of the Arabs (Sundus Hussein Ali, 2012; Naji Shawkat, vol.1, 2002). After his talks with Naji Shawkat, Von Baben called on his government to find a solution to the Arab problem so that the Arabs would not be disappointed (Ibtisam Hammoud Muhammad, 2009).

In light of this, on November 25, 1940, the German government assured the Iraqi politicians of its readiness to support Iraq in the event of a British attack on it. It also warned of the consequences of Iraq indulged in an armed conflict with Britain (Fritz Groppa, vol.2, 1979). Despite the improvement in Iraqi-German relations, the British pressure managed to bring about political changes in Iraq in which the Kilani government was dismissed, which insisted on continuing its contacts with Germany in the hope of getting rid of the British control.

\section{Third: May 1941 movement and the German stance about it}

British planes bombed the Iraqi forces stationed in Habbaniyah on May 2, 1941. The Iraqi Council of Ministers decided to end the services of British officers and civilians working in Iraq, and to restore diplomatic relations with Germany, and to request their assistance (Abd alRazzaq al-Hasani, 1990). Germany showed its support for the Iraqi government in its war against Britain. Hitler recommended that all efforts be made to provide the Kilani government with military aids, and to transfer some aircraft to Iraq (Lukaz Herzoys, 1968). The German government had prepared for this purpose an aerial and geographic survey of Iraq to be used in the event of military operations or airdrops on Iraqi lands (Bondarevsky, 1977).

On April 24, Germany allocated five transport aircraft to transport 100 tons of weapons and military equipment to Iraq and Syria, followed by another 600 tons to be sent through Iran and Turkey. The German aid included 10 warplanes and 50 light tanks, 460 anti-tank cannons and other weapons. As to the financial aids, $£ 3$ million was identified (Walid Abboud Muhammad Shabib Al-Dulaimi, 1999; Jawdat Jalal Abdul Latif AlTikriti, 2013). Germany had also sent airplanes to 
secure the protection of the oil fields and installations, which were expected to be attacked by the British. On May 8, Germany affirmed its commitment to assist Iraq by placing 150 aircraft at the disposal of Iraq as soon the military operations in Terete end. On the 11th of the same month, Groba offered 10,000 dinars to Kilani. He also promised to offer him a million dinars later. Al-Kilani confirmed his readiness to pay the sums of Iraqi products. In return, Groba stipulated the Iraqi government's approval of the German forces' occupation of the oil fields. Due to the circumstances of the war, and despite the protest of the army chiefs, Al-Kilani agreed to the Germany stipulation. (Ibtisam Hammoud Muhammad, 2009). On May 13, two trains arrived loaded with German weapons. The Iraqi government pledged to barter the prices of these weapons for some agricultural and oil products. Accordingly, Iraq agreed to resume pumping oil to the port of Tripoli (Fritz Groppa, vol.2, 1979). As soon as Britain knew of that agreement, it resorted to freezing the funds of Iraq after all the assets of currencies and deposits escaped to Basra, which prompted Kilani to state his government's desire for Germany to place at the disposal of Iraq 3 million pounds of gold as a balance to cover the new paper currency that will be issued by the German presses (Najda Fathy Safwat, 1984). On May 15, the German planes arrived in Mosul. These planes succeeded in raiding the Habbaniyah camp and destroying three British planes, which boosted the morale of the Iraqi army. In light of this, the British planes destroyed a number of German aircraft. However, this did not limit German military activities. After battles that continued until May 21, during which Germany lost sixteen aircraft. The shooting down of German aircraft and replacing them with other aircraft made the German force unable to limit the subsequent British military operations and its occupation of Fallujah for the second time on May 22 of the same year (Ibtisam Hammoud Muhammad, 2009).

When the situation became critical in Baghdad, the German mission left on May 28 to
Mosul. Al-Kilani met Groba and discussed the deteriorating military situation; after the failure of the four colonels' plans and the futility of their resistance, they headed to Khanaqin on May 29. Kilani followed them, seeking political asylum from Iran, and the Iranian authorities agreed (Othman Kamal Haddad, 1952).

Germany lost its influence in Iraq and the Arab East after the failure of its military confrontation and the occupation of Iraq on May 31 by the British forces and stopping the military operations. They also signed the truce on May 31, which included arresting all Germans in Iraq and dissolving all the national and international organizations known for their inclination towards Germany. Nevertheless, despite what happened in Iraq and the end of its role, Germany did not abandon its leaders. Therefore, she asked the representatives of her embassy in Iran to contact Al- Kilani and his group, assuring them that she did not abandon her friends, and that she was ready to protect them and supply them with money and weapons. Al-Kilani took the initiative to deliver the German embassy a statement explaining the developments that occurred in Iraq, the reasons for his failure, and his determination to continue working in order to achieve Arab aspirations for freedom and independence. (Yusra Muhammad Obaid Hamza, 2009).

He suggested to the German ambassador to conclude a military, political and economic cooperation agreement with the German government through which he would ensure his position in Iraq. The German ambassador sent AlKilani's proposal after which a meeting was held in Germany on August 23, 1941 to discuss the future of cooperation with Iraq. Al-Kilani was forced to leave Iran for Turkey on the July 22, 1941. Upon his arrival, Iraqi and Arab politicians gathered around him and authorized him to contact Germany to obtain recognition of his government. Nonetheless, the increasing pressure on the Turkish government from the British and Iraqi governments to hand him over to the Iraqi authorities, prompted Al-Kilani to travel to Germany on October 21, 1941. On December 2, 
he met, the German Foreign Minister, asked him for Germany to recognize him as the head of the government of Iraq in exile and as its foreign minister. On December 22 of the same year, he presented the issue to Hitler and he agreed to it (Najm al-Din al-Sahroudi, 1988).

On July 15, 1941, Al-Kilani met Hitler, and the latter expressed his appreciation for the uprising in Iraq and affirmed his determination to free Iraq from the British control. Despite this, on January 11, 1943, the Iraqi Council of Ministers clarified its stance regarding the Axis countries, considering them countries with hostile stance. Then, on the 13th of the same month, Iraq declared war against it according to the royal will, which was issued on the 13th of the same month (Abd al-Razzaq al-Hasani, History of Ministries, Part 6, 1988). Following the retreat of German forces in the years 1943-1944, the German propaganda began to weaken in Iraq due to the Germans' preoccupation with matters more important than the Arab issue. When the German military situation deteriorated further during 1945, Rashid Ali al-Kilani left Berlin, traveling between a number of European and Arab countries to finally reach The Kingdom of Saudi Arabia as a political refugee (Najm al-Din al-Sahroudi, 1988; Yousra Muhammad Ubaid, 2009).

\section{Conclusion}

The study arrived at several conclusions, including:

1. Germany's growing role in finding a foothold in the Middle East since it achieved its national unity in 1870 . The German penetration in Iraq was not easy, as it was interrupted by the difficulties of several major countries, especially Britain.

2. The strategic planning for Germany in the Middle East was poor as it did not have clear goals in that region. Therefore, its movements there came as if they were just a reaction to the Allied plans and the depletion of Britain's power.

3. The defeat of Germany in the First World War made it interested in regaining its position in Europe and improving its internal conditions, which led to the decline of its international relations, including Iraq.

4. The developments in Iraq in 1941 came as a valuable opportunity for Germany, but its military failure in its war operations affected its political activities in Iraq to the extent that it ended the German role in Iraq.

5. Germany's failures began in the last years of the war that reached its climax in 1943. That signaled the end of Germany's aspirations in the East in general and Iraq in particular. That ended an important stage of German activity in which Iraq was an arena for conflict between Britain and Germany.

\section{References}

Unpublished documents - Iraqi documents Iraqi National Library and Archives documents

[1] 724/311 Iraqi Royal Commission in Cairo.

[2] 729/311 Iraqi Royal Commission in Cairo.

[3] 762/311 Iraqi Royal Commission in Berlin.

[4] Ibtisam Hammoud Muhammad, Germany's stance about the Events in Iraq 1937-1941, Tikrit University Journal of Human Sciences, Volume 16, Issue 6, June 2009.

[5] Ahmad Khudair Abbas, The Scope of Iraqi-Kuwaiti Relations after 1990, Master Thesis, Faculty of Law and Political Science, Beirut Arab University, Beirut, 2014.

[6] Ahmed Kamel Mansour, German Propaganda in Iraq, Analytical Study of News and Articles in Newspapers (Punishment, Country and Independence for the period 1-4-1940 to 1-7-1941, Master Thesis, College of Information, University of Baghdad, 2012.

[7] Dr. Shacht, Colonies from an Economic Point of View, "Al-Muqtatif", (magazine), 
Egypt, Part III, Volume 90, March 1, 1937, Egypt.

[8] Al-Alam Al-Arabia (newspaper), No. 2442,2463, dated February 28 and March 24, 1932.

[9] Ala Hamzah Al-Fatlawi, British Policy towards Turkey 1919-1923, Master Thesis, College of Arts, University of Baghdad, 2000.

[10] ................., British policy towards Turkey 1939-1945, PhD thesis, College of Arts, University of Baghdad, 2009.

[11] Iman Mutab Yahya Al-Nuaimi, The Crisis in the United States of America, Causes and Consequences (1929-1933), PhD thesis, College of Education, AlMustansiriya University, 2003.

[12] Benjamin Eil, Adolf Hitler, from strength to collapse, translated: Fouad Mahalla Saada, Beirut, 1965 (11)

[13] Bondarevsky, Two Policies Toward the Arab World, Moscow, 1977.

[14] Jaafar Abbas Hamidi, Political Developments in Iraq 1941-1953, AnNu'man Press, Najaf, 1976.

[15] Jawad Muhammad Ali Muhammad Rida, Iraqi-German Relations 1871-1914, Master Thesis, Higher Institute for National and Socialist Studies (formerly), AlMustansiriya University, 1982.

[16] Hikmat Sami Suleiman, Iraq Oil, Arab Dar Al-yaqdha, Damascus, 1958.

[17] Jawdat Jalal Kamel Abdul Latif, The British-German Competition in Iraq 19331945, Master Thesis, College of Education, University of Tikrit, 2013.

[18] George Lonzochki, Petroleum and the State in the Middle East, Commercial Office, Beirut, 1961.

[19] Hamid al-Hamdani, Iraq and the repercussions of the Second World War, Civilized Dialogue, No. 5158, May 10, 2016.

[20] Hussam al-Samuk, King Ghazi and his role in the upheaval against Bakr Sidqi's in
1936, Arab Dar of Encyclopedias, Dr. M., 2005

[21] Hussein Tohme Shathir, Iraqi-German Relations 1932-1941, Master Thesis, College of Education / Ibn Rushd, University of Baghdad, 1988.

[22] Hussein Muhammad al-Shabibi, Independence and National Sovereignty, Al-Shaab Press, Baghdad, 1973, pp. 56-71.

[23] Russell Bradon, The Siege of Kut in the War between the English and the Turks in Iraq in 1914-1918, translated by Salim Taha Al-Tikriti and Abdul Majid Yassin Al-Tikriti, Part 2, Baghdad, 1985.

[24] Ruaa Maher Badri Jabal Al-Janabi, Mahmoud Riad and his role in Egyptian and Arab foreign policy 1948-1979, Master Thesis, College of Education, University of Tikrit, 2014.

[25] Sigfried Kogelfrantz, the outcomes of World War II, How did the Russian Reich "liberate" the countries of Eastern Europe? Translated by: Ghanim Muhammad, “Arab Horizons", (magazine), Baghdad, Issue 1, Seventeenth Year, January 1992.

[26] ZY Harshalag, Introduction to the Modern Economic History of the Middle East, translated by: Mustafa Al-Hasani, Beirut, 1973.

[27] Riad Al-Samad, International Relations in the Twentieth Century, Beirut, 1983.

[28] Sami Muslim, The Image of Arabs in the German Federal Press, the Center of the studies of the Arab Unity, Beirut, 1985.

[29] Ambassador Muhammad Al-Saad, Why Did the April / May 1941 Movement Fail in Iraq, "Arab Horizons", (magazine), Baghdad, Issue Eight, Fifteenth Year, August 1990.

[30] Samaan Boutros Farag Allah, Political Relations in the Twentieth Century, The Anglo Library, Cairo, 1974.

[31] Sundus Hussein Ali, Orientations of the Iraqi National Radio, 1936-1958, Master Thesis, College of Education for Women, University of Baghdad, 2012. 
[32] Tariq Ibrahim Sharif, biography and life of King Faisal II (1935-1958), the last king of Iraq, Ghaidaa House for Publishing and Distribution, Dr. M., 2011.

[33] Abdel Khaleq Lashin, highlights on Ali Maher's Ministry's attitude towards the Second World War, "A Documentary Study", The Egyptian Historical Journal, Egypt, Volume Twenty-Four, 1977.

[34] Abd al-Rahman Abd al-Ghani, Nazi Germany and Palestine 1933-1945, Institute of Palestine Studies, Beirut, 1995.

[35] Abdul Razzaq Al-Hasani, Modern Political History of Iraq, Part 1, Sidon, 1948.

[36] C The hidden secrets of May 1941 liberation movement, 3rd Edition, Beirut, 1971.

[37] History of Iraqi Ministries, vol. 4, 5,6, 10, $7^{\text {th }}$ edition, Baghdad, 1977.

[38] Abd al-Fattah Ibrahim, on the road to India, Al-Ahali Press, Baghdad, 1935.

[39] Abdul Majeed Kamel Al-Tikriti, Faisal AlAwal and his role in the establishment of the modern Iraqi state, House of Cultural Affairs, Baghdad, 1991.

[40] Othman Kamal Haddad, The Movement of Rashid Ali al-Kilani in 1941, Beirut, 1952.

[41] Adnan Rashid, German-Arab relations and the attempts to control people in the region from 1871-1945, Arab Horizons, Baghdad, third year, issue 11, July 1978.

[42] Ammar Shaker Mahmoud, The History of the European Diplomacy between the Two Wars, "The Munich Conference in 1938," published and distributed by the July Press, Damascus, 2013.

[43] Ali Mawla, The simplified Arabic Encyclopedia, Part 7, The Modern Library, Beirut, 2010.

[44] Farouk Saleh Al-Omar, The Iraqi-British Treaties and Their Impact on the Internal Politics, 1922-1948, Freedom House, Baghdad, 1977.

[45] Farouk Saleh Al-Omari, May Revolution 1941 and the Axis Countries in British Documents, Baghdad, 2002
[46] Franz von Papen, Memoirs of Franz von Papen, Beirut, Part 2, 1952, p. 7.

[47] 1. Fritz Groppa, Men and Power Centre in the east countries, Part 1, Part 2, translated by Farouk Hariri, Baghdad, 1979.

[48] Fouad Sarrouf, The Great Economic Problem in the Post-War Global Settlement, "Al-Muqatif," (magazine), Egypt, Part V of Volume One Hundred and Six, May 1, 1945.

[49] Kutayba Abdullah Abbas Al-Badri, Baghdad-Berlin Railway and the International Economic Competition Around It, 1871-1914, PhD thesis, Institute of Arab History, Baghdad, 2011.

[50] Lotfi Jaafar Faraj, King Ghazi and his role in the Iraq politics in the local and foreign domains, 1933-1939, Sumer Press, Baghdad, 1987.

[51] Lucaz Herzoys, Hitler's Germany and the Arab East, translated by Abd al-Rahim Mustafa, Dar al-Ma'arif, Egypt, 1968.

[52] Muhammad Shukri Fouad, Studies in the Contemporary European History (19391945), Cairo, 1947.

[53] Muhammad Saleh Mansi, The Arab Awakening Movement in East Asia, Cairo, 1972.

[54] Muhammad Muhammad Salih and Others, The History of Germany in the Nineteenth Century, Baghdad, 1985.

[55] Muhammad Kamal El-Desouki, The History of Germany, Cairo, 1969.

[56] Muhammad Kamal al-Desouki, The Ottoman Empire and the Eastern Matter, Cairo, 1976.

[57] Mahmoud Abdul Wahid Mahmoud, The Commercial and Political Activity of the English East India Company in India (1600-1668), Master Thesis, College of Arts, University of Baghdad, 1993.

[58] Majeed Khadduri, Iraq's Constitutional and Judicial Institutions, Baghdad, 1938.

[59] Musaad Rustum Hammadi Al-Rajhi, Mahmoud Al-Durra and his military and 
political role in Iraq, Master Thesis, College of Education / Ibn Rushd, 2013.

[60] Moaz Hilal Jasim, Winston Churchill's Policy towards the Middle East (TurkeyIran-Iraq) (1939-1945) as an example, unpublished $\mathrm{PhD}$ thesis, College of Arts, Anbar University, 2013.

[61] Mona Muhammad Hassoun Al-Saadi, German-Egyptian Relations 1933-1945, $\mathrm{PhD}$ thesis, College of Education for Girls, University of Baghdad, 2017.

[62] Maurice Crozier, The Contemporary Testament, translated by: Youssef Asaad Dagher, Fred M. Dagher, Awaidat Publications, Beirut, 1970.

[63] Naji Shawkat, Biography and Memories of Eighty Years 1894-1974, Part 1, Baghdad, 1990.

[64] Najm al-Din al-Sahroudi, history did not start tomorrow, facts and secrets about the revolutions of Rashid Ali al-Kilani 41 and 58 in Iraq, $2^{\text {nd }}$ edition, Baghdad, 1988.

[65] Najdat Fathi Safwat, Iraq in the Memoirs of Foreign Diplomats, 2nd Edition, Baghdad, 1984.

[66] 1. From the window of the embassy, The Arabs in Light of British Documents, Riyadh Al-Rayyes, London, 1999.

[67] Nassif Jassim Abbas Al-Ahbabi, Relations between Iran and Nazi Germany 19331945, unpublished MA Thesis, College of Arts, University of Baghdad, 1989.

[68]

Relations

between Turkey and Nazi Germany 19331945, PhD Thesis, College of Arts, University of Baghdad, 1994.

[69] The Abbasid regime, the Zionist-Nazi relations and their impact on Palestine and the Arab liberation movement, 1933-1945, Kuwait, 1984.

[70] Nuri AbdulHamid Khalil, The Political History of the Oil privileges in Iraq, 19251952, $\mathrm{PhD}$ thesis, College of Arts, University of Baghdad, 1975.
[71] Hashem Saleh Al-Tikriti, The German interference in the Arab East prior to the First World War, The Arab Historian, No. 27, Year 12, 1986.

[72] Wissam Hadi Akkar Al-Tamimi, Aziz Sharif and his intellectual and political role in Iraq until 1958, Master Thesis, College of Education / Ibn Rushd, University of Baghdad, 2010.

[73] William Shearer, The History of Hitler's Germany, the rise and fall of the Third Reich, Part 1, translation: Khairy Hammad, Arab Book House, Beirut, 1966.

[74] Walid Abboud Muhammad Shabib alDulaimi, German Policy towards the Arab East (1933-1945), PhD thesis, College of Education / Ibn Rushd, University of Baghdad, 1999.

[75] Yusra Muhammad Obaid Hamzah, Britain's attitudes towards the German activity in Iraq (1933-1945), MA Thesis, College of Education, University of Mosul, 2009.

[76] Yunus Bahri, Secrets of 2 May 1941 and the Iraq-Anglo War, Baghdad, 1968.

[77] Fritz, Redlich ,Hitler,s New Yourk, 1999.

[78] Francis, R. Nicasia,the Third Reich and the Palestine Question.London,1985.

[79] Little, Tom ,Modern Egypt ( Nations of the modern world ),London,1967 .

[80] Mahmoud, Kassim ,Die dipllomatischen Beziehungen Deutschlands zu Agypten 1919-1936 ,Band 6, Lit Verlag Munster - Hamburg ,2000.

[81] otto Hammann, The World Policy of German 1890-1912,London,1926.

[82] Shirer, William .The Rise and fall of the third Reich, A history of Nazi Germany, New York, 1960. 